To cite this article: Adebayo, E. A \& Babalola, Y. T (2020) Awareness and Intention to Use Massive Open Online Courses by Law Students in Osun State, Nigeria. Information Impact: Journal of Information and Knowledge Management, 11:4, 37-47, DOI: https://dx.doi.org/10.4314/iijikm.v11i4.4

To link to this article: https://dx.doi.org/10.4314/iijikm.v11i4.4

\title{
Awareness and Intention to Use Massive Open Online Courses by Law Students in Osun State, Nigeria
}

\author{
${ }^{1}$ Adebayo, E. A \\ ${ }^{1}$ Babalola, Y.T \\ ${ }^{1}$ Information Resources Management Department, Babcock University Library, Ilishan-Remo, Ogun State, \\ Nigeria
}

\begin{abstract}
A survey was carried out among undergraduate law students in universities in Osun State, Nigeria to determine the predictive influence of awareness on intention to use Massive Open Online Courses (MOOCs). Proportionate stratified sampling was used to select 356 out of a population of 3269 students. A validated questionnaire with Cronbach's alpha reliability coefficient of 0.92 was used for data collection. A return rate of $100 \%$ was achieved. Data collected were analyzed using descriptive and binary logistic regression. Findings revealed that awareness of MOOCs significantly predicted intention to use MOOCs by the students (Odds Ratio=1.894; Wald Statistics $=12.413, p=0.000$ ). Findings further revealed that a good number of the respondents intend to use MOOCs $(n=264,78.3 \%)$. The Internet $(n=92)$ was the main source of awareness of MOOCs, but slow internet connectivity $(n=254)$ topped the list of constraints to the use of MOOCs by the students. The study concluded that awareness of MOOCs is critical to its use by undergraduate students in universities in Osun State. It was recommended that law librarians should create awareness of MOOCs among students. Also, law administrators, council of legal education and legal educators should work with the government to improve Internet facilities in the universities to enable law students take full advantage of MOOCs platforms.
\end{abstract}

Keywords Awareness, Massive Open Online Courses, Use, Law Students, Undergraduates

CONTACT Clement C. Adebayo, E. A and Babalola, Y.T ea.adebayo@icloud.com Information Resources Management Department, Babcock University, Ilishan-Remo,Ogun State, Nigeria

2020 The Authors Published with License by Information Impact

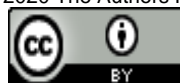




\section{Introduction}

Information and Communication Technology (ICT) has revolutionized all sectors of human life including the educational sector. Education has moved from traditional, regular classroom to include online distance education mode, thereby reaching more students in a more effective and efficient manner. According to Saba (2011), distance education, also known as long-distance learning, is a form of education where the teacher and students physically separated during instruction. Traditionally, this type of learning involved correspondence courses where the student interacted with the school via post. Today, various ICT tools are used to facilitate teacher-student and student-student relationship in distance education. In recent times, distance education has become an established part of the educational world with a recent form of distance learning being the Massive Open Online Courses (MOOCs). MOOCs are educational or instructional multimedia modules made available over the Internet with unlimited number of participant (Pilli \& Admiral, 2017). They are generally open (free access), participatory, distributed, and part of lifetime self-directed learning network. Consequently, everyone is allowed to participate and work together either to develop existing knowledge or attain new knowledge, thereby paving way for continuous education.

The growing number of MOOCs and learner participation in MOOCs are attributed to their many advantages. At the end of year 2018, more than 900 universities around the world had offered roughly 11,400 MOOC, with about 2,000 new courses (Shah, 2018) while 101 million new learners signed up for at least one MOOC (Zhu, Bonk \& Sari, 2018). The recorded success and potential benefits of the Massive Open Online Courses (MOOCs) notwithstanding, there seem to be low use of the technology among Africans. Gloy (2018) reported that Africans account for only $16 \%$ of University of Cape Town's online courses on Coursera and FutureLearn. Studies conducted among librarians in Nigerian show that they are not ignorant of MOOCs and their benefits for professional development, but their use of the technology is still low ( Soyemi \& Babalola, 2018). Kpolovie and Iderima (2016) reported low readiness for MOOCs use by undergraduates in Nigeria; an indication that intention to use MOOCs is low among this group.

Alotumi (2019) defined intention to use as a mental attitude to make a choice and then take action to implement the choice. Intention to use a system is the likelihood that a person will employ an information system in carrying out some tasks (Zakaria, Anual, Halif, Jamaluddin, Ismail \& Ariffin, 2018). The importance of studying students' intention to use massive online courses is to be able to determine the eventual use of the platform for either their continuous development or lifelong learning. Most of the studies on intention to use MOOCs were measured with Ajzens' (1991) Theory of Planned Behavior (TPB). The theory includes three core constructs such as Attitude, Subjective Norm and Perceived Behavioral Control (PBC) which leads to intention to perform an action and then the actual performance of the action. Attitude signifies the individual beliefs that applying a certain technology will have a positive outcome to the individual. Subjective Norm is the intention of the individual to use a technology based on the opinion of the social groups that are of importance to the individual, while $\mathrm{PBC}$ is defined as the individuals' perception of the ease or difficulty of performing the behavior of interest. Research has shown that intention to use technology-based platform and systems such as MOOCs may be influenced by a mix of factors which include security of the platform and cost (Anouze \& Alamro, 2019); peer influence, computer self-efficacy, perceived risk and perceived usefulness (Rallis, Chatzoudes, Symeonidis, Aggelidis \& Chatzoglou, 2019; Okcu, Koksalmis, Basak \& Calisir, 2019) curiosity and job advancement (Zo \&Ciganek, 2015) and awareness of the technology (Sezgin, Ozkan-Yildirim \& Yildirim, 2017; Kayyali, Peletidi, Ismail, Hashim \& Bandeira, 2017).

Awareness means an understanding of the existence or presence of a phenomenon. Awareness changes the perspective of human thinking regarding situations. Opeke and Odunlade (2011) defined awareness as a knowledge of something which exists or understanding of a particular situation based 
on experience or information. It can be seen as a state wherein a person is cognizant of some information when that information is directly available (Reinhardt, Mletzko, Sloep, \& Drachsler, 2012). Literature has shown that when users are aware of the benefits, advantages, characteristics and disadvantages that MOOCs platforms offer that they may use the platform for their continuous education (Muzafarova \& Kaya, 2014). It may be correct to assume that intension to use MOOCs is low because law students are not aware of its existence or its benefits. Therefore, this study examined the predictive influence of awareness of MOOCs on intention to use MOOCs by undergraduate law students in universities in Osun State, Nigeria.

\section{Research questions}

The study provided answers to the following research questions:

- What is the level of awareness of MOOCs by law students in Universities in Osun State?

- Do law students in Universities in Osun State intend to use MOOCs?

- How does awareness predict intention to use MOOCs among law students in the study area?

\section{Hypothesis}

The only hypothesis tested in this study is as stated:

$\mathbf{H}_{\mathbf{0}}$ : Awareness of MOOCs has no predictive influence on intention to use MOOCs by law students in universities in Osun State, Nigeria.

\section{Literature review}

Both conceptual and empirical literature on intention to use MOOCs, awareness of MOOCs and the nexus between awareness of MOOCs and intention to use MOOCs were reviewed to give a robust understanding of the concepts in this topic and to better situate the study in extant literature.

\section{Intention to Use Massive Open Online Courses}

Alotumi (2019) defined intention to use as a mental attitude to make a choice and then take action to carry it out the choice(s) made. In the research work carried out by Zhou (2016) on the acceptance of MOOCs among Chinese university students, the study revealed that students' attitude toward MOOCs and Perceived Behavioural Control (PBC), were significant determinants of an intention to use them. Intention to use has been brought to the fore by various authors, as seen in the work of Sezgin, OzkanYildirim, and Yildirim (2017) on the awareness and use of mHealth by Physicians. The study found that physicians intend to use mHealth apps and it was at an average level of 59\% of the total variance. Further findings also revealed that user perception and intentions were important factors in technology use. Similarly, Kayyali, Peletidi, Ismail, Hashim, and Bandeira (2017)'s study on the awareness and use of mHealth apps in England found that intention to use mHealth app was low as most patients were not aware of the benefits of the app. However, further findings reveal that intention to use the app was found to be high among diabetics' patients, having been recommended to them by their physicians.

Various authors have put forward several factors that affect students' intention to use MOOCs. According to Huang, Zhang, and Liu (2017), students' intention to use MOOCs is affected by factors such as technological characteristics, teacher subject knowledge, and interactivity. This presupposes that the nature of MOOCs platform, the course content and the teacher-student or student-student collaboration are what influences students' intention to use MOOCs platform. Contrary to this opinion is that factors such as job advancement or technology curiosity influences intention to use MOOCs (Alraimi, Zo \& Ciganek, 2015). The study by Ayoade (2015) on factors influencing students' behavioural intention to adopt and use mobile learning in higher educational 
institutions found that performance expectancy, effort expectancy and social influence had a significant positive effect on the behavioural intention of the students to adopt and use mobile learning.

\section{Awareness of Massive Open Online Courses}

Despite being a fairly recent phenomenon, massive open online courses (MOOCs), have attracted wide interest from people around the world. According to Liyanagunawardena (2015), MOOCs provide the educational opportunities in courses offered by prestigious universities, and also in interest from the vast educational community (Clow, 2013). In the study conducted by Dhanani, Chavda, Patel and Tandel (2016) on awareness and utilization of massive open online course and video series as continuous learning tools for faculties, only $20(18.52 \%)$ faculties out of 108 were aware of the availability of online free courses and websites such as EdX, Coursera, MIT Open Course Ware, and others. In addition, 14 reported having enrolled in the courses at least once. Shakya, Shrestha, and Manandhar (2016) also found out in their study on awareness of MOOC among college students in the western region of Nepal that 184 out of 227 students surveyed were not aware of MOOCs. Only 7.93\% were familiar with Khan Academy a variant of MOOCs and $7.05 \%$ were frequently using it. This presupposes that as many students were not aware of Khan Academy, they were also not aware of MOOCs, implying the centrality of driving awareness for MOOCs.

Another study by Muzafarova and Kaya (2014) on awareness and use of MOOCs among International Black Sea University students in Georgia, suggested that both awareness and the use of MOOCs were very low. From the findings, sixty-one percent (61\%) of students had never taken any MOOC. Although $65.67 \%$ of the students have broadband internet connection and all the necessary tools, only $39 \%$ used it for educational purposes (distance learning) at least once. Soyemi and Babalola's (2018) study on the awareness and use of MOOCs among academic librarians in Ogun state, revealed that more than half $(61.4 \%)$ of academic librarians in Ogun state were aware of MOOCs whereas, only (42.9\%) enrolled for MOOCs. Similarly, in a survey carried out by Kaushik (2015) on the perceptions of Library and Information Science (LIS) professionals towards Massive Open Online Course (MOOC) in India, the researcher found out that LIS professionals knew about MOOC through e-resources and search engines but they had never participated in any MOOC due to reasons of unfamiliarity with online environment and also because they had not heard about MOOCs. Furthermore, Wang and Sun's (2017) study on China college students' awareness, participation and evaluation of MOOCs revealed that Chinese college students' awareness and understanding of MOOC was extremely low.

\section{Awareness and Intention to Use Massive Open Online Courses}

Although research evidence show contradictory findings, there is no doubt that awareness has some effect on intention to use MOOCs. Awareness is a critical factor in the use of an information system. Whilst some scholars believe that awareness of a system does not necessarily affect intention to use it, others are of the opinion that the higher the level of awareness, the higher the intention to use the system. Ogbeide, Aribaba, Fapohunda, and Omoregie (2017), from their empirical assessment of factors influencing intention to use forensic accounting services in Nigeria, found that awareness has no significantly influence on organizations' intention to use forensic accounting in fraud detection and prevention. This corresponds with the study by Mamman, Ismail, Said and Kamalludeen (2016) on the awareness and procedural knowledge as predictors of students' intention to use BookMyne. The study revealed that there was a high level of intention to use the system by students of International Islamic University Malaysia (IIUM) despite having low knowledge of the system. This presupposes that there is no relationship between awareness of BookMyne and intention to use same. In a study on the awareness and utilization of information resources among polytechnic lecturers in Nigeria by Opeke and Odunlade (2011), it was revealed that a weak positive correlation $(r=0.37, p=0.012<0.05)$ 
existed between awareness and utilization of information resources. This suggests that awareness may not necessarily trigger intention to use or the eventual use of a system.

Conversely, Soheila (2014) observed from his study of Malaysian teachers' intention to use GeoGebra in teaching mathematics in the classrooms that prior knowledge of MOOCs and its perceived usefulness, will aid students' intention to use it. This finding is consistent with that of Sezgin, Ozkan-Yildirim, and Yildirim (2017) who investigated the awareness and use of mHealth by Physicians in Europe and Asia. The study found that physicians intend to use mHealth apps due to their awareness of the apps and its benefits to healthcare. Similarly, the study by Kayyali, Peletidi, Ismail, Hashim, and Bandeira (2017) revealed that awareness is a major factor that affects intention to use software. The authors researched the awareness and use of mHealth apps in England and found that intention to use mHealth app was low as most patients were not aware of the apps and their potential benefits. Although, further findings revealed that intention to use mHealth app was found to be high among diabetics' patients, due to their awareness of the existence of the app. Wang and Sun (2017)'s study on MOOCs awareness, participation and evaluation among Chinese college students revealed thatstudents' intention to use MOOCs were low due to their lack of awareness of what MOOCs entail. Also, Tahiru and Kamaludeen (2018) emphasized that awareness and intention to use technology are strongly connected. Their study on indicators of students' intention to use MOOCs for academic purposes revealed that the number of non-users of MOOCs $(n=149)$ far outnumber the users $(\mathrm{n}=41)$ which implies that awareness does trigger students' intention to use. The results further showed that for every unit of increase in students' awareness, there is a corresponding increase in students' intention to use MOOCs. This suggests that students who become aware of MOOCs and are familiar with its usefulness for lifelong skills acquisition, develop a positive attitude to it and subsequently develop the intention to use it.

\section{Methodology}

Descriptive survey research design was employed among 3269 undergraduate law students in universities in Osun State, Nigeria. Osun State was selected because it has the highest number of universities offering law programs in Nigeria. With the aid of Taro Yamane (1967) formula for calculating sample size for finite population, a sample size of 356 was determined. Proportionate stratified sampling technique was used to select the sample size. A structured questionnaire was used for data collection. Awareness of MOOCs was measured using a 4-point scale in the following format: 4= Highly Aware (HA), 3=Aware (A), 2=Partially Aware (PA), 1=Not Aware (NA), while intention to use MOOCs was measured as a dichotomous response of Yes or No. The instrument was developed by the researcher and was pretested among 30 law students of Babcock University. Cronbach's alpha coefficient of each construct in the instrument was above 0.7, indicating that the instrument had internal consistency. A total of three hundred and fifty-six (356) copies of the questionnaire were administered and all (100\%) were retrieved and considered usable. Frequency counts, percentages, mean and standard deviation were used to analyze data to describe the variables while binary logistic regression was used to test the hypothesis because of the dichotomous nature of the dependent variable. 


\section{Results}

Research Question 1: What is the level of awareness of MOOCs by law students in Universities in Osun State?

Table 1: Level of Awareness of Massive Open Online Courses (MOOCs)

\begin{tabular}{|c|c|c|c|c|c|c|}
\hline Awareness of the benefits of MOOCS & Not Aware & $\begin{array}{l}\text { Partially } \\
\text { Aware }\end{array}$ & Aware & $\begin{array}{l}\text { Highly } \\
\text { Aware }\end{array}$ & Mean & $\begin{array}{l}\text { Std. } \\
\text { Dev }\end{array}$ \\
\hline $\begin{array}{l}\text { Enrolling in a MOOC can increase your } \\
\text { knowledge }\end{array}$ & $68(19.8)$ & $76(22.1)$ & $93(27.0)$ & $107(31.1)$ & 2.69 & 1.11 \\
\hline $\begin{array}{l}\text { Participating in MOOCs can improve } \\
\text { your skills }\end{array}$ & $75(21.7)$ & $74(21.4)$ & $104(30.1)$ & $92(26.7)$ & 2.62 & 1.10 \\
\hline $\begin{array}{l}\text { You can be given a certificate at the end } \\
\text { of a MOOC }\end{array}$ & $85(24.6)$ & $65(18.8)$ & $106(30.6)$ & $90(26.0)$ & 2.58 & 1.12 \\
\hline $\begin{array}{l}\text { Participating in MOOCs can boost your } \\
\text { career growth }\end{array}$ & $94(27.3)$ & $66(19.1)$ & $97(28.2)$ & $87(25.3)$ & 2.51 & 1.14 \\
\hline \multicolumn{5}{|l|}{ Group Mean } & 2.61 & 0.99 \\
\hline \multicolumn{7}{|l|}{$\begin{array}{l}\text { Awareness of how to participate in } \\
\text { MOOCS }\end{array}$} \\
\hline $\begin{array}{l}\text { You need internet and ICT tools to } \\
\text { participate in MOOCs }\end{array}$ & $62(18.5)$ & $57(17.0)$ & $107(31.8)$ & $110(32.7)$ & 2.79 & 1.09 \\
\hline Knowledge of how to use MOOCs & 118(34.2) & $85(26.4)$ & $89(25.8)$ & $53(15.4)$ & 2.22 & 1.08 \\
\hline $\begin{array}{l}\text { Knowledge of how to register for a free } \\
\text { MOOC }\end{array}$ & $118(34.2)$ & $91(26.4)$ & $96(27.8)$ & $40(11.6)$ & 2.17 & 1.03 \\
\hline $\begin{array}{l}\text { Knowledge of how to participate in } \\
\text { MOOCs from anywhere }\end{array}$ & 127(36.7) & $98(28.3)$ & $75(21.7)$ & $46(13.3)$ & 2.12 & 1.05 \\
\hline \multicolumn{5}{|l|}{ Group Mean } & 2.36 & 0.91 \\
\hline \multicolumn{7}{|l|}{ Awareness of different types of MOOCS } \\
\hline OpenClassrooms & $138(40.4)$ & $45(13.2)$ & $72(21.1)$ & $87(25.4)$ & 2.32 & 1.24 \\
\hline Open Learning & $136(39.8)$ & $62(18.1)$ & $68(19.9)$ & $76(22.2)$ & 2.25 & 1.20 \\
\hline Coursera & 149(43.6) & $50(14.6)$ & $55(16.1)$ & $88(25.7)$ & 2.24 & 1.25 \\
\hline edX & $159(46.4)$ & $52(15.2)$ & $72(21.0)$ & $60(17.5)$ & 2.10 & 1.17 \\
\hline Open2Study & $155(45.5)$ & $53(15.5)$ & $80(23.5)$ & $53(15.5)$ & 2.09 & 1.14 \\
\hline FutureLearn & $163(47.8)$ & $64(18.8)$ & $61(17.9)$ & $53(15.5)$ & 2.01 & 1.13 \\
\hline OpenEdx & $165(48.5)$ & $60(17.6)$ & $68(20.0)$ & $47(13.8)$ & 1.99 & 1.11 \\
\hline Udemy & $173(50.9)$ & $58(17.1)$ & $59(17.4)$ & $50(14.7)$ & 1.96 & 1.13 \\
\hline Canvas Network & $173(51.2)$ & $54(16.0)$ & $63(18.6)$ & $48(14.2)$ & 1.96 & 1.13 \\
\hline Udacity & $181(52.9)$ & $56(16.4)$ & $56(16.4)$ & $49(14.3)$ & 1.92 & 1.12 \\
\hline Iversity & $179(52.6)$ & $61(17.9)$ & $53(15.6)$ & $47(13.8)$ & 1.91 & 1.11 \\
\hline MOOC-ED & $178(52.5)$ & $63(18.6)$ & $53(15.6)$ & $45(13.3)$ & 1.90 & 1.10 \\
\hline \multicolumn{5}{|l|}{ Group Mean } & 2.06 & 0.91 \\
\hline \multicolumn{7}{|c|}{ Grand Mean $=2.25 ;$ Standard Deviation $=0.83$} \\
\hline
\end{tabular}

Decision rule: Mean (1.0-1.49 = Very Low Level of Awareness of MOOCs; Mean (1.50-2.49 = Low Level of Awareness of MOOCs; Mean (2.50-3.49 = High Level of Awareness of MOOCs; Mean (3.50-4.0 = Very High Level of Awareness of MOOCs.

The results on Table 1 show that awareness of MOOCs is generally low among undergraduate law students in Osun State, Nigeria (Grand Mean=2.25, Std. = 0.83). Out of the three constructs used to measure awareness of MOOCs, only awareness of the potentials/ benefits of participating in MOOCs was high as observed from the Group Mean (Mean $=2.61$, Std. $=0.99$ ). This is because the mean response for all the statements used to capture awareness of the potentials/benefits of participating in MOOCs were equally high (>2.51). awareness of how to participate in MOOCS and awareness of different types of MOOCs (Mean $=2.06$, Std. $=0.91$ ) were low among the respondents. With regard to awareness of how to participate in MOOCs, the results show that the Group mean was low (Mean = 2.36 , Std. $=0.91$ ). Likewise, the mean response of all the statements were below 2.50 except for You 
need internet and ICT tools to participate in MOOCs $($ Mean $=2.79$, Std. $=1.09)$. This shows that undergraduate law students in Osun state university are not really aware of how to participate in MOOCs. The results further showed that awareness of different types of MOOCs has the lowest Group Mean of the three indicators of awareness of MOOCs (Mean= 2.06, Std. $=0.91$ ). This is expected since the mean response for awareness of all the listed MOOCs were low $(<2.50)$. From these results, it can be deduced that awareness of MOOCs is generally low among undergraduate law students in Osun State, Nigeria. Although they are highly aware of the benefits and potentials of MOOCs, their awareness of the various types of MOOCs and how to participate therein is low.

Research Question 2: Do law students in Universities in Osun State intend to use MOOCs? Table 2: Intention to Use MOOCs

\begin{tabular}{|l|l|l|}
\hline Statement & $\begin{array}{l}\text { Yes } \\
\text { Freq (\%) }\end{array}$ & $\begin{array}{l}\text { No } \\
\text { Freq (\%) }\end{array}$ \\
\hline & $264(78.3)$ & $73(21.7)$ \\
\hline I intend to use MOOCs & & \\
\hline
\end{tabular}

Table 2 shows the distribution of respondents by intention to use MOOCs. The results shows that the majority $(n=264,78.3 \%)$ intend to use MOOCs.

Research Question 3: How does awareness predict intention to use MOOCs among law students in universities in Osun State?

Binary logistic regerssion analysis was carried out to test the null hypothesis:

$\mathbf{H}_{\mathbf{0}}$ : Awareness of MOOCs has no predictive influence on intention to use MOOCs by law students in universities in Osun State, Nigeria.

Table 3: Binary Logistic Regression of Awareness and Intention to Use MOOCs

\begin{tabular}{|l|l|l|l|l|l|l|l|l|}
\hline \multicolumn{7}{|c|}{$\begin{array}{c}\text { Hosmer and Lesmeshow Test }=10.940, p=0.205 \\
\text { Cox \& Snells's R Square=0.040; } \\
\text { Nagelkerke R Square=0.063 }\end{array}$} \\
\hline & $\boldsymbol{\beta}$ & Wald & df & $\mathbf{p}$ & O.R & \multicolumn{2}{|c|}{$\mathbf{9 5 \%}$ C.I.for O.R } \\
\cline { 2 - 8 } & & & & & & Lower & Upper \\
\hline Awareness of MOOCs & .639 & 12.413 & 1 & .000 & 1.894 & 1.328 & 2.703 \\
\hline Constant & -.018 & .002 & 1 & .963 & .982 & & \\
\hline $\begin{array}{l}\text { Dependent Variable: Intention to use MOOCs } \\
\text { Sig. at } \mathbf{p}<\mathbf{0 . 0 5}\end{array}$
\end{tabular}

Source: Researcher's Study, 2019

The results on Table 3 shows that awareness of MOOCs $(\beta=0.639$; Odds Ratio (O.R) $=1.8947$; $\mathrm{p}<0.05)$ significantly predict intention to use MOOCs by law students in Universities in Osun State hence, the stated null hypothesis is rejected. The Hosmer and Lemeshow Test of $10.940(p=0.205)$ indicated good model fit for the binary logistic model obtained. Cox \& Snell R Square and the Nagelkerke R Square are 0.040 and 0.063, suggesting that awareness of MOOCs explain between $4.0 \%$ and $6.3 \%$ of the variability in intention to use MOOCs by law students in Universities. From the results, we conclude that awareness of MOOCs has a significant predictive influence on intention to use MOOCs by law students in Universities in Osun State.

\section{Discussion}

Research question one was formulated to ascertain the level of awareness of MOOCs by law students in Universities in Osun State. The finding shows that the level of awareness of MOOCs by law 
students in Universities in Osun State is low. The finding is consistent with several studies such as Dhanani et al (2016) who perceived that only 20 (18.52\%) faculties out of 108 were aware of the availability of online free courses and websites such as EdX, Coursera, MIT Open Course Ware, and others. Lending credence to this view, Shakya et al. (2016) found out in their study on awareness of MOOC among college students in the western region of Nepal that 184 out of 227 students surveyed were not aware of MOOCs. Only $7.93 \%$ were familiar with Khan Academy a variant of MOOCs and $7.05 \%$ were frequently using it. However, the finding was inconsistent with that of Soyemi and Babalola's (2018) who revealed that more than half (61.4\%) of academic librarians in Ogun state were aware of MOOCs. Likewise, Kaushik (2015) found out that LIS professionals knew about MOOC through e-resources and search engines, but they had never participated in any MOOC due to reasons of unfamiliarity with online environment. The disparity in the findings could be that this study only investigated the level of awareness of MOOCs by law students in Universities in Osun State while those in other academic institutions like Colleges of Education, Polytechnics, Monotechnics were not considered.

Research question two was formulated to find out if law students in Universities in Osun State intend to use MOOCs. Findings reveals that law students intend to use MOOCs. The finding agreed with that of Rashid and Asghar (2016) who discovered that students believed that technology could enhance their academic performance thereby developing an intention to use it. The finding also corroborates that of Hew and Cheung (2014) who found that students intend to sign up for MOOCs to extend their current knowledge, satisfy their information curiosity and take up personal challenge. It however negates Muhammad, Mustapha, and Haruna's (2016) finding that Kano State university students do not intend to use MOOCs due to its user unfriendliness, inadequate internet connectivity, power instability and cost of enrolments.

The hypothesis was formulated to find out if theawareness of MOOCs has a significant predictive influence on intention to use MOOCs by law students in Universities in Osun State. Findings reveal that awareness of MOOCs has a significant predictive influence on the intention to use MOOCs by law students in Universities in Osun State. The null hypothesis was thus rejected as the findings imply that awareness of MOOCs explained between $4.0 \%$ and $6.3 \%$ of the variability in intention to use MOOCs by law students in Universities. Findings of the study corroborate that of Tsigilis and Togia's (2010) on awareness and use of Electronic Information Resources by Aristotle University of Thessaloniki graduate students, the study revealed that the main problem associated with the non-use of the technology by graduate students was lack of adequate awareness. Another study by Muzafarova and Kaya (2014) on awareness and use of MOOCs among International Black Sea University students in Georgia, suggested that awareness was low which led to the low usage of MOOCs. Whilst some scholars believe that awareness of a system does not necessarily necessitate the intention to use it (Mamman, Ismail, Said \& Kamalludeen, 2016; Ogbeide et al, 2017), others are of the opinion that the higher the level of awareness, the higher the intention to use the system (Muzafarova \& Kaya, 2014; Alzubi, Al-Dubai, \& Farea, 2017; Tahiru\&Kamaludeen, 2018).

Also, in disagreement with the findings is that of Ogbeide, et al (2017) empirical assessment of factors influencing intention to use forensic accounting services in Nigeria, who noted that awareness do not significantly influence organizations' intention to use forensic accounting in fraud detection and prevention in the Nigeria context. This corresponds with the study by Mamman et al (2016) who revealed that International Islamic University Malaysia (IIUM) students had low levels of awareness of BookMyne, although the students showed a high level of intention to use the system despite having low knowledge of the system. Similarly, Soyemi and Babalola's (2018) study on the awareness and use of MOOCs among academic librarians in Ogun state, revealed that more than half $(61.4 \%)$ of academic librarians in Ogun state were aware of MOOCs whereas, only (42.9\%) enrolled 
for MOOCs. The rich supply of literature has emphasized the need to raise awareness of MOOCs in order to promote intention to use MOOCs by law students in Universities in Osun State.

\section{Conclusion}

This study established the predictive influence of awareness on intention to use massive open online courses by law students in Osun State, Nigeria. The findings showed that intention to use MOOCs is high among the students. Although the students are highly aware of the benefits of MOOCs, they are not so aware of the various MOOCs that are available and how to effectively participate in them. Intention to use a technology can only translate to actual use when the prospective users have the requisite knowledge and enabling facilities.

\section{Recommendations}

Based on the findings of this study, it is recommended that law librarians should help create awareness of the different MOOCs and how law students can participate in them. Also, law administrators, council of legal education, legal educators and decision-makers should work with the government to provide internet access for law students in universities in Osun State, Nigeria. This will encourage them to transform their intention to use MOOCs to actual use

\section{References}

Ajzen, I. (1991). The theory of planned behavior. Organizational behavior and human decision processes, 50(2), 179-211. http://doi.org/10.1016/0749-5978(91)90020-T

Alraimi, K. M., Zo, H. J., \& Ciganek, A. P. (2015). Understanding the MOOCs continuance: The role of openness and reputation. Computers \&Education. Retrieved from http://dx.doi.org/10.1016/j.compedu.2018.08.006

Alotumi, M. (2019). EFL learning beyond the wall with MALL: College students' perceptions. IGI Global. DOI: 10.4018/978-1-7998-2116-8.ch007

Alzubi, M. M., Farea, M. M. \& Al-Dubai, M. M. (2017). The mediating role of awareness in the intention to use internet banking among SMEs in Yemen. Journal of Internet Banking and Commerce, 22 (2).

Anouze, A. L. M. \& Alamro, A. S. (2019). Factors affecting intention to use e-banking in Jordan. International Journal of Bank Marketing, 38 (1), 86-112. Retrieved from https://www.emerald.com/insight/content/doi/10.1108/IJBM-10-2018-

0271/full/pdf?title=factors-affecting-intention-to-use-e-banking-in-jordan

Ayoade, O. B. (2015). Factors influencing students' behavioural intention to adopt and use mobile learning in higher educational institutions in Nigeria: An example of Ekiti State University, Ado-Ekiti. International Journal of Emerging Technology and Advanced Engineering 5(4), 307-313. Retrieved from https://pdfs.semanticscholar.org/c786/9dc5b320db3a9ff113231e99e9ad1802a8c9.pdf

Clow, D. (2013). MOOCs and the funnel of participation. Retrieved from http://oro.open.ac.uk/36657/1/DougClow-LAK13-revised-submitted.pdf

Dhanani, J. V., Chavda, N., Patel, N. \& Tandel, K. (2016). Awareness and utilization of massive open online course (MOOC) and video series as continuous learning tools for faculties. International Journal of Medical Science, Public Health, 5, 1540-1543.

Gloy, R. (2018). MOOCs: The challenge of Africa. Research and Innovation, 5. Retrieved from https://www.technologist.eu/moocs-the-challenging-move-into-africa/

Huang, L., Zhang, J., \& Liu, Y. (2017). Antecedents of student MOOC revisit intention: Moderation effect of course difficulty. International Journal of Information Management37, 84-91. Retrieved from https://www.sciencedirect.com/science/article/pii/S0268401216301797 
Kaushik, A. (2015). Perception of library and information science professionals towards Massive Open Online Course: A survey. World Digital Libraries, 8 (2), 113-126. Retrieved from https://content.iospress.com/articles/world-digital-libraries-an-

international.journal/wd18203?resultNumber=0\&totalResults=549\&start=0\&q=Perception+of + Library+and+Information+Science+Professionals+towards+Massive+Open+Online+Course \&resultsPageSize $=10 \&$ rows $=10$

Kayyali, R., Peletidi, A., Ismail, M. Hashim, Z. \& Bandeira, P. (2017). Awareness and use of mHealth apps: A study from England. Pharmacy, 5, 1-14.

Liyanagunawardena, T. R. (2015). Massive open online courses. Humanities, 4, 35-41; DOI:10.3390/h4010035. Retrieved from www.mdpi.com/2076-0787/4/1/35/pdf

Mamman, B., Ismail, Z., Said, M. N. H. \&Kamalludeen, R. M. (2016). Awareness and procedural knowledge as predictors of students' intention to use BookMyne: An exploratory study. Regional Conference on Engineering Education (RCEE) Conference Paper, 231-236. Retrieved from https://www.researchgate.net/publication/311648806

Muzafarova, T. \& Kaya, E. (2014). Survey of awareness of Massive Open Online Courses (MOOC) A case of international black sea university students, Georgia, Journal of Education; 3 (2). Retrieved from https://www.researchgate.net/publication/300061216

Ogbeide, S. O., Aribaba, F. O., Fapohunda, F. M. \& Omoregie, L. C. (2017). Empirical assessment of factors influencing intention to use forensic accounting services in Nigeria. International Journal of Research in Business Studies and Management, 4 (5), 24-31.

Okcu S., Koksalmis, H. G., Basak E., Calisir F. (2019). Factors affecting intention to use big data tools: An extended technology acceptance model. Lecture Notes in Management and Industrial Engineering. Springer, Cham. Retrieved from https://doi.org/10.1007/978-3030-03317-0_33

Opeke, R. O. \& Odunlade, R. O. (2011). Awareness and utilisation of information resources among Polytechnic lecturers in Nigeria.Samaru Journal of Information Studies, 11 (1 \& 2), $59-66$.

Pilli, O., \& Admiraal, W. (2017). Students' learning outcomes in Massive Open Online Courses (MOOCs): Some suggestions for course design, 7 (1), 46-71. Retrieved from https://doi.org/10.2399/yod.17.001

Rallis S., Chatzoudes D., Symeonidis S., Aggelidis V., Chatzoglou P. (2019). Factors affecting intention to use e-government services: The case of non-adopters. Lecture Notes in Business Information Processing, 341. Springer, Cham

Reinhardt, W., Mletzko, C., Sloep, P. B. \& Drachsler, H. (2012). Understanding the meaning of awareness in research networks. Conference Paper. Retrieved fromhttps://www.researchgate.net/publication/230640624

Saba, F. (2011). Distance education in the United States: Past, present, future. Educational Technology. Retrieved from https://www.academia.edu/27893586/Distance_education _in_the_United_States_Past_present_future

Sezgin, E., Ozkan-Yildirim, S. \& Yildirim, S. (2017). Investigation of Physicians' awareness and use of mHealth apps: A mixed method study. Health Policy and Technology, 6, 251-267. DOI: http://dx.doi.org/10.1016.j.hlpt.2017.07.007

Shakya, M., Shrestha, S. \& Manandhar, R. (2016). Awareness of MOOC among college students: A study of far western region of Nepal. Retrieved from https://www.researchgate.net/publication/306057436

Soheila, A. (2014). Malaysian teachers' intention to use GeoGebra in teaching mathematics in the classrooms based on their perceived usefulness, ease of use, and current competencies of using GeoGebra (Unpublished master's thesis, International Islamic University). Retrieved from http://thesisonline.org 
Soyemi, O. D. \& Babalola, Y. T. (2018). Awareness and use of massive open online courses among academic librarians in Ogun state, Nigeria. Information Impact, Journal of Information and Knowledge Management, 9 (1), 1-11. Retrieved from https://dx.doi.org/10.4314/iijikm.v9i1.1

Tahiru, M. \& Kamaludeen, R. (2018). Indicators of students' intention to use massive open online courses for academic purposes. Malaysian Online Journal of Educational Technology (MOJET), 6 (3).

Tsigilis, N. \& Togia, A. (2010). Awareness and use of electronic information resources by education graduate students: Preliminary results from the Aristotle university of Thessaloniki. Qualitative and Quantitative Methods in Libraries, International Conference, Chania Crete Greece. Retrieved from http://doi.org/10.1142/9789814299701_0058

Wang, N. \& Sun, S. (2017). MOOC: awareness, participation and evaluation from China college students. Advances in Social Science, Education and Humanities Research (ASSEHR),95, 229-234.

Yamane, Taro. (1967). Statistics: An Introductory Analysis, 2nd Ed., New York: Harper and Row. Retrieved from http://www.sciepub.com/reference/180098

Zakaria, I., Anual, N., Halif, M. M., Jamaluddin, M., Ismail, W. S. A. W., \& Ariffin, N. (2018). The intention to use on e-Learning portal: A case study of i-Learn portal at universiti teknologi MARA Cawangan Kelantan. International Journal of Academic Research in Business and Social Sciences, 8 (11), 711-721

Zhou, M. (2016). Chinese university students' acceptance of MOOCs: A self-determination perspective. Computers \& $\quad \& \quad$ Education.Retrieved from http://dx.doi.org/10.1016/j.compedu.2015.10.012. 